\title{
Engineering Solar Energy in the Fourth Grade Science Classroom
}

\section{Ms. Christina Hobson Foster, Arizona State University}

Foster is a Ph.D. student in Engineering Education dedicated to improving the status of engineering education in K-12. His research focus is on identifying ways to motivate K-12 students to learn engineering and on ways to develop systems thinking, a necessary habit of mind for engineers of the 21st century. Currently he is in his third year of studies and is focused on the QESST educational research program with the goal of evaluating and developing resources for renewable energy instruction under the direction of Dr. Jenefer Husman.

\section{Dr. Jenefer Husman, Arizona State University}

Dr. Jenefer Husman received a doctoral degree in Educational Psychology from the University of Texas at Austin in 1998. She served as an Assistant Professor at the University of Alabama from 1998 to 2002, when she moved to Arizona State University. In 2008 she was promoted by ASU to Associate Professor. Dr. Husman serves as the Director of Education for the Quantum Energy and Sustainable Solar Technology Center - an NSF funded Engineering Research Center. Dr. Husman has been a guest editor of Educational Psychology Review, served on editorial board for top educational research journals, and currently sits on the editorial board of Learning and Instruction and Teachers College Record. In 2006 she was awarded the U.S. National Science Foundation CAREER grant award and received the Presidential Early Career Award for Scientists and Engineers from the President of the United States. She has conducted and advised on educational research projects and grants in both the public and private sectors, and served as an external reviewer for doctoral dissertations outside the U.S. She publishes regularly in peer-reviewed journals and books, and has held both elected and appointed offices in the American Psychological Association (APA). Dr. Husman was a founding member and first President of the Southwest Consortium for Innovative Psychology in Education. She currently serves as the elected Co-Coordinator of the Motivation Special Interest Group of the European Association for Research on Learning and Instruction.

\section{Christine Mendoza}




\title{
Engineering Solar Energy in the Fourth Grade Science Classroom
}

\begin{abstract}
The National Academy of Engineering has called for the integration of engineering into K-12 science curriculum in order to improve student achievement and motivation in science and mathematics. Further, a framework for the Next Generation Science Standards is set to be released which will challenge K-12 schools to align the learning of content with scientific and engineering practice. Teachers will need to be supported in implementing curricula, pedagogy, and assessments for the teaching of integrated science and engineering around core content areas, including energy topics. This engineering solar energy research project aims to address this momentum towards integrated classroom learning of science and engineering by supporting a fourth grade educator from a local Southwest elementary school with learning experiences that will help develop capacity in integrating engineering into the science class, specifically by implementing an engineering design project on solar energy. This work is in the beginning stages of a design research methodology, in which an instructional model for integrating engineering into the elementary science classroom and its support curriculum will be repeatedly documented, analyzed, and revised
\end{abstract}

In Spring 2012, a solar engineering design challenge was introduced in the fourth grade classroom. A researcher from the Quantum Energy and Sustainable Solar Technologies (QESST) worked alongside the fourth grade educator to provide in-classroom professional development to introduce the engineering design challenge to the students using modeling, whiteboarding, and the engineering design process as instructional techniques. This learning experience took place during science classroom time for a period of two and a half weeks with 24 students. Reflections were collected from the researcher and teacher throughout the process in order to revise and extend the learning experience for the following school year. Revisions were made to emphasize the iterative, systematic nature of the engineering design process and to enhance student learning of energy transfer. Further, the learning experience was expanded to include an electrical circuits component.

In September and October 2012, researchers provided the same fourth grade educator with five weeks of in-classroom professional development during science classroom time to introduce the revised and extended solar engineering design challenge. The educator and 24 students again experienced for themselves engineering design projects, learned about the engineering design process, and learned about energy concepts, specifically, electricity, electrical circuits, and renewable energy through hands-on experiences. Data from this iteration will be presented in this paper.

The research team found that the learning experiences resulted in enhanced knowledge of energy-related content. Pre- and post- content knowledge assessment on solar energy topics was used for this measure. Adaptive goals for learning science content was not found to be statistically significant different. The curriculum will be revised for classroom structures for student learning that value hands-on exploration of science and engineering concepts. 


\section{Introduction}

The National Academy of Engineering (NAE) has called for the integration of engineering into K-12 science curriculum in order to improve student achievement and motivation in science and mathematics. Specifically, engineering education has the opportunity to improve students' scientific and technical literacy and increase the preparedness of students pursuing careers in scientific and technical fields. There is a unique opportunity for engineering education to fuel a more interconnected and effective STEM curriculum while promoting the habits of mind that are essential $21^{\text {st }}$ century skills in addition to the scientific and engineering practices that are essential to representing the work of scientists and engineers (e.g. constructing scientific explanations and developing engineering solutions) ${ }^{1,2}$. Engineering habits of mind are systems thinking, creativity, optimism, collaboration, communication, and attention to ethical considerations ${ }^{1}$. The core of real-world science and engineering relies on the ability to critically analyze the natural and designed world as well as utilize these $21^{\text {st }}$ century skills and scientific and engineering practices. This is lost in the school's recipe-like design of classroom science. The disconnect between real-world science and engineering and classroom science is one of the most persisting deficiencies within the U.S. public education system ${ }^{2}$. K-12 engineering education initiatives are being developed to improve the state of science education to more accurately reflect the work of scientists and engineers ${ }^{1,2}$. However, K-12 science education will also have to reform and support the work of engineering education if improvements in the science classroom are to be made.

In response to this, A Framework for K-12 Science Education: Practices, Crosscutting Concepts, and Core Ideas has been developed by the Carnegie Corporation of New York and the National Research Council and represents a new conceptual framework for science education. The impetus for this project stems from the growth of knowledge of science, increased understanding of the learning and teaching of science, and the need for scientific and engineering practices to be represented in the science classroom. The framework is organized within three dimensions: science and engineering practices, crosscutting concepts to unify science and engineering, and disciplinary core ideas (one of which is engineering and technology). The vision for the framework is to actively engage students in multiple years of science and engineering and to enable students in applying crosscutting concepts to understand the core ideas of science and engineering fields. The framework supports the goals of the NAE by integrating engineering into the science classroom and representing the $21^{\text {st }}$ Century skills and engineering practices into the three dimensions of the framework. Their goal in doing this is to make the work of scientists and engineers explicit and cohesive. For example, the crosscutting concepts section of the framework includes patterns, cause and effect, systems and system models, and structure and function. According to the NAE, these are important concepts that are required in engineering to develop sound scientific knowledge that is then used to inform and optimize an engineering design ${ }^{1}$. The new science framework communicates the crosscutting concepts as knowledge that bridges science and engineering and helps reach STEM literacy goals, which is a goal of the NAE as well. The framework includes an emphasis on science and engineering practices. Specifically, within the framework's eight key practices both developing and using models and designing engineering solutions as well as engaging in argumentation from evidence are two crosscutting science and engineering practices that are essential to the framework. The framework importantly states that the practices can be used in different ways for science and engineering 
due to the different goals that engineering has compared to science. The framework makes note that engineering practices are used to design a solution that meets given specifications and constraints and then to evaluate what is needed to improve the design; whereas, scientific studies may not be driven by a practical application but instead uses the practices to develop an explanation to a phenomenon of interest. The framework shows that a cumulative, cohesive experience for both science and engineering will lead to a deeper understanding for science and engineering. In the core ideas, engineering is represented with three core ideas - engineering design, interdependence of science, engineering, and technology, and the influence of engineering, technology, and science on the society and the natural world. These ideas are represented in many of the engineering education initiatives overviewed in the NAE's publication Engineering in K-12 Education: Understanding the Status and Improving the Prospects ${ }^{1}$. The framework's commitment to integrating engineering into the science classroom and representing engineering learning objectives as the work that drives professional engineering is evident. This framework represents a new way of teaching and learning science and engineering. The framework will be soon rolled out to K-12 schools of participating states and will require teachers to be prepared to teach science in a new way.

Despite the framework's attainable approach to engineering and cohesiveness with the NAE's goals, introducing engineering in the K-12 science classrooms will be challenging. Engineering has been marginalized due to teacher's discomfort with engineering principles, an already loaded science curriculum along with limited science classroom time, and the misconception that engineering will take away from the goals of science learning ${ }^{1}$. These outstanding issues will have to be addressed if engineering is to have success in the science classroom. Additionally, engineering education initiatives that have been represented in the classroom are typically taught in a way that is disconnected and separate from the science curriculum ${ }^{1}$. In elementary science classrooms especially, engineering is rarely implemented and in the cases where it is (e.g. building bridges or designing a carrier to protect an egg when dropping it) engineering principles and practices are separate from the curriculum and the science behind it is often misrepresented and not expanded upon ${ }^{3}$. The new science framework addresses these issues, but teachers will need intensive support from engineering educators to mentor them. Additionally, teachers will need to be provided with appropriate pedagogical strategies that will aid in implementing engineering in the K-12 science classroom.

This work in progress research project addresses this need by supporting a fourth grade educator from a local Southwest elementary school with engineering learning experiences that will help develop proficiency in teaching and implementing engineering in the elementary science classroom. Researchers used engineering design and modeling as the core pedagogical strategies because they are foundational elements of engineering and support the goals of the new science framework and NAE. Engineering design allows children to engage in the practices of engineering and take ownership over their learning. In engineering design, students explore their own solutions and explanations to the problem at hand and become a part of communities of practice as they participate in discourse about their designs ${ }^{1,5}$. By moving through the engineering design process, students are able to actually do science and engineering and make deeper connections to the links between science and engineering. However, engineering design as a pedagogical strategy is not without its challenges. Engineering design as practiced by professional engineers is not easily learned by students or taught by teachers ${ }^{1}$. The hands-on 
aspect of design can easily overwhelm the systematic method of the engineering design process ${ }^{6}$. Further, novice learners of design tend to rely upon trial-and-error methods rather than the systematic approach used by professional engineers and spend too much time in the first phase of the engineering design process, defining the problem ${ }^{7,8}$.

Modeling as a pedagogical strategy can be used to overcome some of the challenges associated with the teaching and learning of engineering design. Modeling provides a method for students to assess the validity of their designs and understand what may happen if their design is constructed and implemented ${ }^{4,9}$. Modeling also allows for the exploration of the students' designs by providing students with a way to think about how their designs are structured, how the parts of their design function, and how their designs behave ${ }^{4}$. This then provides opportunities for students to make connections to the scientific concepts that drive the behaviors of their models. Teachers can support students in developing a more sophisticated understanding by scaffolding the connections that the students need to make ${ }^{10}$.

Whiteboarding is an aspect of modeling instruction that supports student learning of engineering and scientific practices ${ }^{11,12}$. Whiteboarding is performed in a classroom by having students come together for a group meeting and communicate the results at the end of each class. This allows students to reflect upon their work, develop explanations for their engineering decisions, engage in critique and evaluation of their own and other students' work, and develop scientific explanations for the processes that they observe in their engineering models ${ }^{11,12}$. Because whiteboards are generally large and erasable, they allow for sharing, negotiation, and open discourse of conceptualization, modeling, and problem solving, which greatly enhances and enables modeling instruction in a classroom. This instructional process for building scientific and engineering knowledge is vital to improving science and engineering education.

\section{Methods}

This work in progress describes the beginning stages of developing an instructional model for integrating engineering into the elementary science classroom using a design-based research method approach, which requires constant iterative documentation, analysis, and revision ${ }^{14}$. The end goal of this research is to explain how the instructional model is effective while also deliberately attempting to understand what did not work, so as to improve upon for each iteration. The project relies upon the collection of instructional artifacts, student artifacts (e.g. engineering design notebooks and design models), informal interviews, and daily reflections from the educator and researcher to revise the curriculum. The second iteration of this project also included an assessment of science and engineering content knowledge and a measure of classroom goal structure. The analysis of these assessments from the second iteration is presented in this document. This research relies upon a long-term partnership with the school district and its success will depend upon multiple iterations of implementing the instructional model in a real-life setting, the fourth grade classroom.

Because the instructional model relies upon engineering design and modeling, an engineering design project, designing a solar oven, was used to model energy concepts (e.g. heat transfer) and engage students in engineering practices. Energy is both a core idea and crosscutting concept in the new science framework. The framework communicates the importance of understanding 
energy concepts by stating, "The ability to examine, characterize, and model the transfers and cycles of matter and energy is a tool that students can use across virtually all areas of science and engineering", Energy is often a difficult concept to explore in the classroom due to its complexity and instruction can often teach it in an abstract way; by using engineering design and modeling, this research intends to make the scientific concepts on energy visible and tangible for students. For educators, solar ovens are widely seen in science and engineering education program. Even though they have become a familiar engineering outreach project within K-12 schools, they are often not accompanied with instruction that scaffolds the core scientific concepts of energy ${ }^{1}$. Additionally, the practices of science and engineering are often not made explicit during the execution of completing solar oven projects. Engineering education researchers from the Quantum Energy and Sustainable Solar Technologies (QESST) used the solar oven design project along with scaffold instruction as a model for integrating engineering into the science classroom.

This research project documents the challenges of teaching engineering in an elementary science classroom using engineering design and modeling. This paper overviews the first two iterations of the project and presents a focused analysis from the efforts of the second iteration. The QESST researchers involved in this project are a former science educator with 13 years of experience and specialization in modeling instruction, two Ph.D. students in engineering education, and a University Faculty member who specializes in educational psychology. The fourth grade educator has 5 years of experience and has not taught engineering in his classroom prior to this research project. During both iterations, the science classroom had 24 fourth grade students. The instruction was tailored to the widely used BSCS 5E model of instruction (which tailors instruction to the following phases: engage, explore, explain, elaborate, and evaluate) to accommodate the school district's request to teach engineering design and modeling within this frame $^{13}$.

\section{Iteration 1}

In Spring 2012, a solar engineering design challenge was introduced in the fourth grade classroom. A researcher from the Quantum Energy and Sustainable Solar Technologies (QESST) worked alongside the fourth grade educator to provide in-classroom professional development to teach the engineering design challenge to the students using modeling, whiteboarding, and the engineering design process as instructional strategies. This learning experience took place during science classroom time for a period of two and a half weeks with 24 students. The aim of the first iteration was to pilot test the engineering instructional strategies and its support curriculum for its developmental appropriateness with fourth grade students and feasibility within the science class. Professional development was provided to the fourth grade educator through the form of cognitive apprenticeship. This took the form of a QESST researcher - who has 13 years of science teaching experience and specialization in modeling instruction - modeling the instructional methods during every class session, and then meeting with the educator after each session to elaborate upon the instructional strategies as well as any successes and failures with the implementation. Since the instruction was provided by the QESST researcher, the fourth grade educator was given the opportunity to observe the instructional strategies, learn how to scaffold the engineering and science content, and observe students' engagement with the content. The QESST researcher and educator worked together to document the outcomes of this implementation. The QESST researcher conducted informal interviews with the students and 
educator. Further, written reflections from the educator and researcher were collected, instructional artifacts (e.g. presentations), and student artifacts (e.g. engineering design notebooks and solar oven models) were collected throughout this iteration. The QESST research team met on a regular basis to discuss the project. The collection of these interviews and artifacts were used to make changes actively during the instructional period. These changes were focused on strategies for delivering instruction of engineering design and whiteboarding.

Students worked in groups of four to five. The table below documents an overview of each phase of the curriculum that was conducted and its associated learning goals, engineering and scientific practices that were targeted, and $21^{\text {st }}$ Century skills. The engineering and scientific practices were taken from A Framework for K-12 Science Education: Practices, Crosscutting Concepts, and Core Ideas, and the $21^{\text {st }}$ Century skills were taken from the NAE's habits of mind in Engineering in K-12 Education: Understanding the Status and Improving the Prospects ${ }^{1,2}$.

Table 1

Iteration 1 for the Solar Engineering Learning Experiences and its Associated Learning Goals

\begin{tabular}{|c|c|c|c|c|}
\hline 5E stage & $\begin{array}{c}\text { Learning } \\
\text { Experience }\end{array}$ & Core Content & $\begin{array}{c}\text { Scientific and } \\
\text { Engineering } \\
\text { Practices }\end{array}$ & $21^{\text {st }}$ Century Skills \\
\hline Engage & $\begin{array}{l}\text { The students } \\
\text { engaged in a } \\
\text { discussion } \\
\text { about what to } \\
\text { wear on a } \\
\text { hiking field } \\
\text { trip on a hot } \\
\text { day. They } \\
\text { discussed } \\
\text { colors and } \\
\text { materials for } \\
\text { clothing. }\end{array}$ & $\begin{array}{l}\text { - Energy can } \\
\text { take many } \\
\text { forms, one of } \\
\text { which is heat. } \\
\text { - Energy can } \\
\text { be transferred } \\
\text { between } \\
\text { objects or } \\
\text { systems. } \\
\text { Heat transfer } \\
\text { occurs when } \\
\text { two systems } \\
\text { are at } \\
\text { different } \\
\text { temperatures. } \\
\text { As } \\
\text { temperature } \\
\text { increases, } \\
\text { more energy } \\
\text { is added to a } \\
\text { system. }\end{array}$ & $\begin{array}{l}\text { - Asking } \\
\text { questions for } \\
\text { science } \\
\text { - Engaging in } \\
\text { argument from } \\
\text { evidence } \\
\text { - Obtaining, } \\
\text { evaluating, and } \\
\text { communicating } \\
\text { information }\end{array}$ & $\begin{array}{l}\text { - Creativity } \\
\text { - Collaboration } \\
\text { - Communication }\end{array}$ \\
\hline Explore & $\begin{array}{l}\text { Students } \\
\text { planned and } \\
\text { conducted an } \\
\text { experiment to }\end{array}$ & $\begin{array}{l}\text { - Energy in the } \\
\text { form of heat } \\
\text { is thermal } \\
\text { energy. }\end{array}$ & $\begin{array}{l}\text { - Planning and } \\
\text { carrying out } \\
\text { investigations } \\
\text { - Asking }\end{array}$ & $\begin{array}{l}\text { - Creativity } \\
\text { - Collaboration } \\
\text { - Communication }\end{array}$ \\
\hline
\end{tabular}




\begin{tabular}{|c|c|c|c|c|}
\hline & $\begin{array}{l}\text { investigate } \\
\text { how colors } \\
\text { influence the } \\
\text { transfer of } \\
\text { radiant energy } \\
\text { to thermal } \\
\text { energy. }\end{array}$ & $\begin{array}{l}\text { Thermal } \\
\text { energy } \\
\text { allows us to } \\
\text { heat our } \\
\text { homes, cook } \\
\text { food, etc. } \\
\text { - Energy in the } \\
\text { form of light } \\
\text { is radiant } \\
\text { energy. } \\
\text { - Radiant } \\
\text { energy is } \\
\text { solar energy } \\
\text { and travels to } \\
\text { the earth in } \\
\text { rays } \\
\text { (electromagn } \\
\text { etic waves) } \\
\text { Radiation is } \\
\text { the transfer } \\
\text { of heat } \\
\text { energy } \\
\text { through } \\
\text { space } \\
\text { Certain } \\
\text { colors absorb } \\
\text { light better } \\
\text { than others. } \\
\text { Lighter } \\
\text { colors reflect } \\
\text { more of the } \\
\text { sun's radiant } \\
\text { energy so } \\
\text { they are } \\
\text { cooler to the } \\
\text { touch. }\end{array}$ & $\begin{array}{l}\text { questions for } \\
\text { science } \\
\text { - Engaging in } \\
\text { argument from } \\
\text { evidence }\end{array}$ & \\
\hline Explain & $\begin{array}{l}\text { Students } \\
\text { collected and } \\
\text { analyzed data } \\
\text { from their } \\
\text { experiment on } \\
\text { how colors } \\
\text { influence the } \\
\text { transfer of } \\
\text { energy. }\end{array}$ & $\begin{array}{l}\text { - Certain } \\
\text { colors absorb } \\
\text { light better } \\
\text { than others. } \\
\text { Lighter } \\
\text { colors reflect } \\
\text { more of the } \\
\text { sun's radiant } \\
\text { energy so }\end{array}$ & $\begin{array}{l}\text { - Using } \\
\text { mathematical } \\
\text { and } \\
\text { computational } \\
\text { thinking } \\
\text { - Analyzing and } \\
\text { interpreting } \\
\text { data } \\
\text { - Engaging in }\end{array}$ & $\begin{array}{l}\text { - Creativity } \\
\text { - Collaboration } \\
\text { - Communication }\end{array}$ \\
\hline
\end{tabular}




\begin{tabular}{|c|c|c|c|c|}
\hline & & $\begin{array}{l}\text { they are } \\
\text { cooler to the } \\
\text { touch. }\end{array}$ & $\begin{array}{l}\text { argument from } \\
\text { evidence } \\
\text { - Obtaining, } \\
\text { evaluating, and } \\
\text { communicating } \\
\text { information }\end{array}$ & \\
\hline Elaborate & $\begin{array}{l}\text { Students } \\
\text { continued their } \\
\text { investigation } \\
\text { by planning } \\
\text { and conducting } \\
\text { an experiment } \\
\text { to determine } \\
\text { how various } \\
\text { materials } \\
\text { influence the } \\
\text { transfer of } \\
\text { energy. }\end{array}$ & $\begin{array}{l}\text { - Certain } \\
\text { materials are } \\
\text { better } \\
\text { conductors of } \\
\text { heat. } \\
\text { - Conduction } \\
\text { is the transfer } \\
\text { of heat by } \\
\text { one thing } \\
\text { touching } \\
\text { another. } \\
\text { - An insulator } \\
\text { is a material } \\
\text { that limits the } \\
\text { amount of } \\
\text { heat that } \\
\text { passes } \\
\text { through it. }\end{array}$ & $\begin{array}{l}\text { - } \text { Planning and } \\
\text { carrying out } \\
\text { investigations } \\
\text { - Asking } \\
\text { questions for } \\
\text { science } \\
\text { - Using } \\
\text { mathematical } \\
\text { and } \\
\text { computational } \\
\text { thinking } \\
\text { - Engaging in } \\
\text { argument from } \\
\text { evidence } \\
\text { - Obtaining, } \\
\text { evaluating, and } \\
\text { communicating } \\
\text { information }\end{array}$ & $\begin{array}{l}\text { - Creativity } \\
\text { - Collaboration } \\
\text { - Communication }\end{array}$ \\
\hline Evaluation & $\begin{array}{l}\text { Students then } \\
\text { applied their } \\
\text { knowledge of } \\
\text { color and } \\
\text { materials in } \\
\text { energy transfer } \\
\text { to an } \\
\text { engineering } \\
\text { design } \\
\text { challenge. } \\
\text { Students were } \\
\text { given the } \\
\text { challenge of } \\
\text { designing and } \\
\text { building a solar } \\
\text { oven using a } \\
\text { pizza box and } \\
\text { other provided } \\
\text { materials such } \\
\text { as felt, } \\
\text { cellophane, }\end{array}$ & $\begin{array}{l}\text { - The } \\
\text { engineering } \\
\text { design } \\
\text { process is } \\
\text { iterative and } \\
\text { systematic. } \\
\text { - The } \\
\text { engineering } \\
\text { design } \\
\text { process is } \\
\text { comprised of } \\
\text { many stages, } \\
\text { beginning } \\
\text { with } \\
\text { identifying a } \\
\text { problem. } \\
\text { Solar energy } \\
\text { can be } \\
\text { harnessed } \\
\text { with solar } \\
\text { collectors }\end{array}$ & 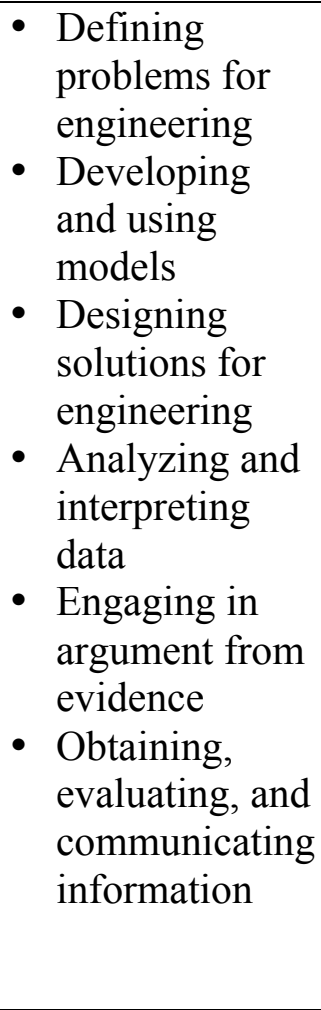 & 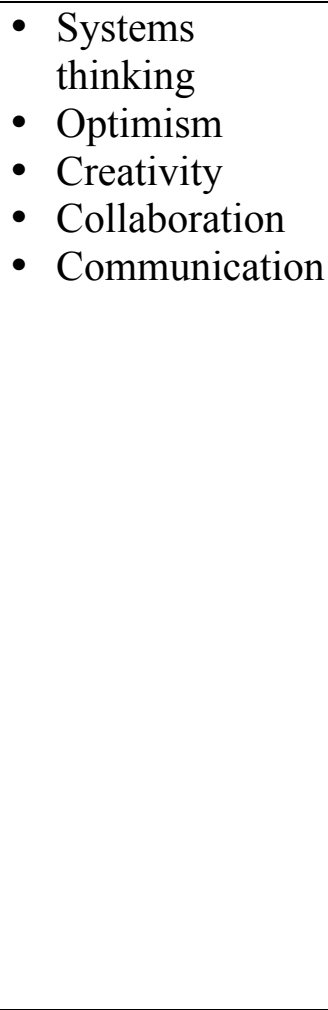 \\
\hline
\end{tabular}




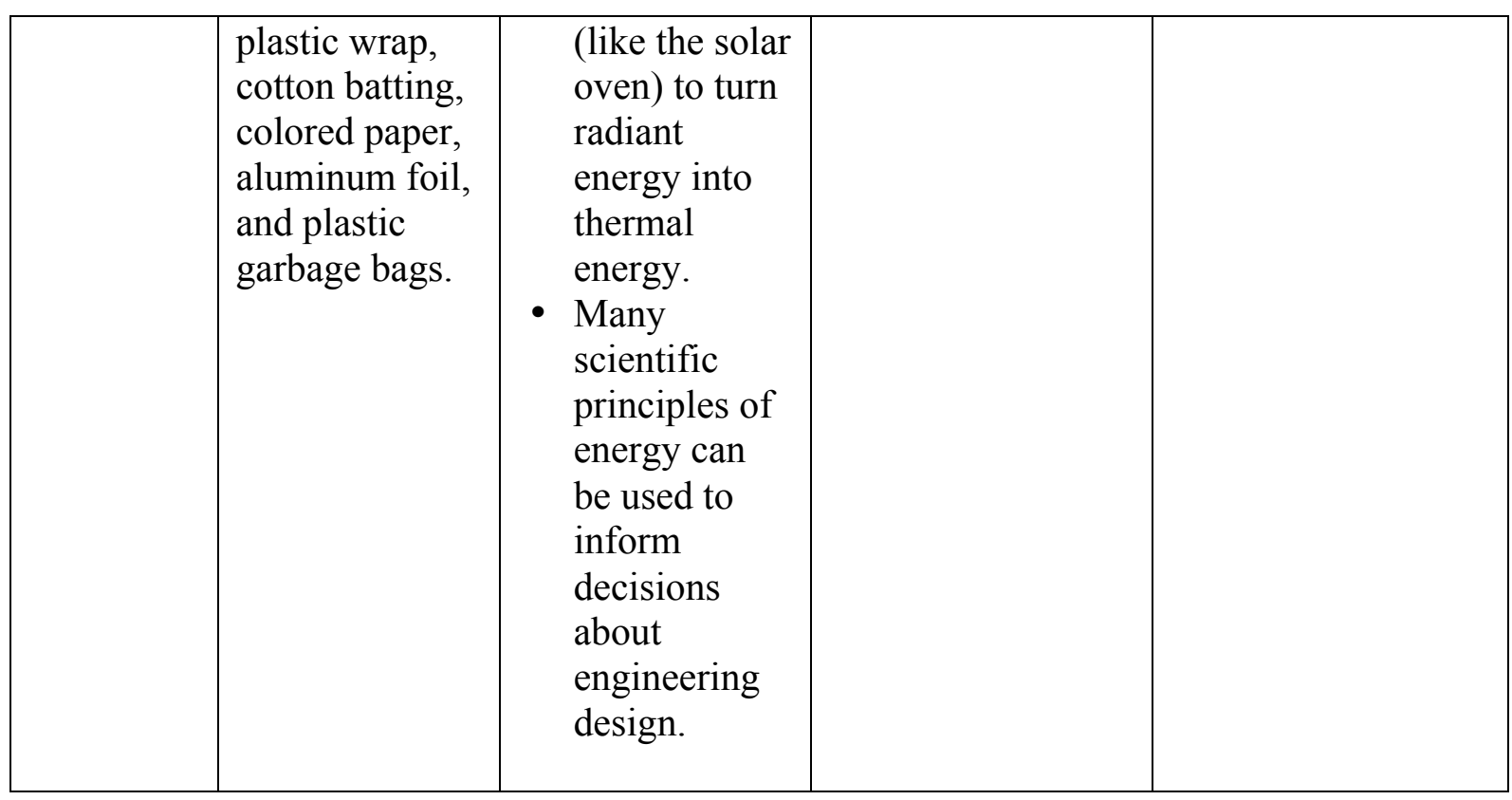

By the end of instruction, the QESST research team expected students to understand that energy is transferred between objects and systems, specifically that energy radiated from the sun is transferred to Earth by light. When this light is absorbed, it warms Earth and objects on Earth (e.g. solar oven). Further, the QESST research team expected the fourth grade students to understand that heating is one type of process for transferring energy and that heat transfer occurs when two systems are at different temperatures. Energy moves out of higher temperature objects and into lower temperature ones. This transfer happens in three different ways-by conduction within solids, by convection (the flow of liquid or gas), and by radiation.

As for science and engineering practices, the QESST research team expected the students to understand that science and engineering uses a key set of practices to design systems. Among these key practices are that engineering begins with a problem or need to be solved. Also, models in science are used to create explanations about natural phenomena (in this case heat transfer), and in engineering models are used to test proposed systems (e.g. system to cook a hot dog) and to recognize the strengths and limitations of their designs. Engineers must also gather data for analysis of how effective their designs are. Analysis allows engineering to compare different solutions and determine how well each one meets specific design criteria.

The QESST researchers also expected instruction to support adaptive motivational goal orientations. Specifically, students would be more focused on learning the material (mastery goals) than on performing better than their peers (performance goals). Additional positive motivational outcomes expected were an increase in science oriented future goals. Because the purpose of this first iteration was to pilot the learning unit, assessments were not collected to measure the gains in content knowledge and goal orientations. These assessment tools were organized and developed for their use in the second iteration. 
In September and October 2012, researchers from QESST provided the same fourth grade educator with five weeks of in-classroom professional development during science classroom time to introduce the revised and extended solar engineering design challenge. The instructional period was extended to included an electrical circuits unit in order to meet the demands of the state standards and model to the fourth grade educator strategies for using engineering design and modeling for this additional instructional unit. The educator and 24 students experienced for themselves the engineering design process through the engineering design project, and learned about energy concepts, specifically, electricity, electrical circuits, and renewable energy.

Students worked in groups of four to five. Table 2 documents an overview of each phase of the electrical circuits curriculum that was conducted and its associated learning goals, engineering and scientific practices that were targeted, and $21^{\text {st }}$ Century skills. The engineering and scientific practices were taken from A Framework for K-12 Science Education: Practices, Crosscutting Concepts, and Core Ideas, and the $21^{\text {st }}$ Century skills were taken from the NAE's habits of mind in Engineering in K-12 Education: Understanding the Status and Improving the Prospects ${ }^{1,2}$. The other parts of the curriculum can be referenced in Table 1. Major changes were not made to the learning goals of this curriculum from iteration 1 to 2 ; changes instead were made to the instructional strategies.

Table 2

Iteration 2 for the Solar Engineering Learning Experiences and its Associated Learning Goals

\begin{tabular}{|c|c|c|c|c|}
\hline 5E stage & $\begin{array}{c}\text { Learning } \\
\text { Experience }\end{array}$ & Core Content & $\begin{array}{c}\text { Scientific and } \\
\text { Engineering } \\
\text { Practices }\end{array}$ & $\begin{array}{c}21^{\text {st }} \text { Century } \\
\text { Skills }\end{array}$ \\
\hline Engage & $\begin{array}{l}\text { Students engaged } \\
\text { in a dramatic } \\
\text { representation in } \\
\text { which one } \\
\text { student, playing } \\
\text { the role of a } \\
\text { battery, had to } \\
\text { pass energy to } \\
\text { another student, } \\
\text { playing the role } \\
\text { of a light bulb. }\end{array}$ & $\begin{array}{l}\text { - Energy can } \\
\text { be } \\
\text { transferred. } \\
\text { - Electricity is } \\
\text { a form of } \\
\text { energy. }\end{array}$ & $\begin{array}{l}\text { - } \text { Asking } \\
\text { questions for } \\
\text { science } \\
\text { - Engaging in } \\
\text { argument from } \\
\text { evidence } \\
\text { - Obtaining, } \\
\text { evaluating, and } \\
\text { communicating } \\
\text { information }\end{array}$ & $\begin{array}{l}\text { - } \text { Creativity } \\
\text { - Collaboration } \\
\text { - Communication }\end{array}$ \\
\hline Explore & $\begin{array}{l}\text { Students were } \\
\text { given materials } \\
\text { and challenged to } \\
\text { construct a circuit } \\
\text { to illuminate a } \\
\text { light bulb. }\end{array}$ & $\begin{array}{l}\text { Electrical } \\
\text { circuits } \\
\text { transfer } \\
\text { electrical } \\
\text { energy. }\end{array}$ & $\begin{array}{l}\text { - Planning and } \\
\text { carrying out } \\
\text { investigations } \\
\text { - Asking } \\
\text { questions for } \\
\text { science } \\
\text { - Engaging in } \\
\text { argument from }\end{array}$ & $\begin{array}{l}\text { - Creativity } \\
\text { - Collaboration } \\
\text { - Communication }\end{array}$ \\
\hline
\end{tabular}




\begin{tabular}{|c|c|c|c|c|}
\hline & & & evidence & \\
\hline Explain & $\begin{array}{l}\text { Students } \\
\text { developed and } \\
\text { explained } \\
\text { physical and } \\
\text { mental models for } \\
\text { their circuits. } \\
\text { Students drew } \\
\text { diagrams of the } \\
\text { various circuits } \\
\text { they constructed } \\
\text { and then engaged } \\
\text { in critique and } \\
\text { argumentation to } \\
\text { identify why } \\
\text { some circuits } \\
\text { worked and other } \\
\text { did not. Students } \\
\text { began to create a } \\
\text { working model of } \\
\text { how energy flows } \\
\text { through a circuit } \\
\text { by adding arrows } \\
\text { to their diagrams. }\end{array}$ & $\begin{array}{l}\text { - Models are } \\
\text { useful for } \\
\text { explaining } \\
\text { scientific } \\
\text { concepts. } \\
\text { - Electrical } \\
\text { circuits } \\
\text { transfer } \\
\text { electrical } \\
\text { energy. } \\
\text { - Electricity } \\
\text { can flow } \\
\text { through a } \\
\text { circuit if } \\
\text { there is a } \\
\text { power } \\
\text { source and a } \\
\text { closed } \\
\text { circuit. }\end{array}$ & $\begin{array}{l}\text { - Developing } \\
\text { and using } \\
\text { models } \\
\text { - Analyzing and } \\
\text { interpreting } \\
\text { data } \\
\text { - Engaging in } \\
\text { argument from } \\
\text { evidence } \\
\text { - Obtaining, } \\
\text { evaluating, and } \\
\text { communicating } \\
\text { information }\end{array}$ & $\begin{array}{l}\text { - Creativity } \\
\text { - Collaboration } \\
\text { - Communication }\end{array}$ \\
\hline Elaborate & $\begin{array}{l}\text { Students designed } \\
\text { and conducted an } \\
\text { experiment to see } \\
\text { which materials } \\
\text { were good } \\
\text { conductors of } \\
\text { electrical energy. }\end{array}$ & $\begin{array}{l}\text { - Conductors } \\
\text { are things } \\
\text { that allow } \\
\text { heat and } \\
\text { electricity to } \\
\text { easily pass } \\
\text { through } \\
\text { them. } \\
\text { - Insulators } \\
\text { are things } \\
\text { that do not } \\
\text { allow heat } \\
\text { and } \\
\text { electricity to } \\
\text { easily pass } \\
\text { through } \\
\text { them. }\end{array}$ & $\begin{array}{l}\text { - Planning and } \\
\text { carrying out } \\
\text { investigations } \\
\text { - Developing } \\
\text { and using } \\
\text { models } \\
\text { - Asking } \\
\text { questions for } \\
\text { science } \\
\text { - Engaging in } \\
\text { argument from } \\
\text { evidence } \\
\text { - Obtaining, } \\
\text { evaluating, and } \\
\text { communicating } \\
\text { information }\end{array}$ & $\begin{array}{l}\text { - Creativity } \\
\text { - Collaboration } \\
\text { - Communication }\end{array}$ \\
\hline Evaluate & $\begin{array}{l}\text { Students reflected } \\
\text { in their } \\
\text { engineering } \\
\text { notebooks about } \\
\text { what they had }\end{array}$ & $\begin{array}{l}\text { See } \\
\text { objectives } \\
\text { listed above. }\end{array}$ & $\begin{array}{l}\text { - Analyzing and } \\
\text { interpreting } \\
\text { data } \\
\text { Engaging in } \\
\text { argument from }\end{array}$ & $\begin{array}{l}\text { - Creativity } \\
\text { - Collaboration } \\
\text { - Communication }\end{array}$ \\
\hline
\end{tabular}




\begin{tabular}{|c|c|c|c|c|}
\hline & $\begin{array}{l}\text { learned about } \\
\text { circuits. }\end{array}$ & & $\begin{array}{l}\text { evidence } \\
\text { - Obtaining, } \\
\text { evaluating, and } \\
\text { communicating } \\
\text { information } \\
\end{array}$ & \\
\hline $\begin{array}{l}\text { Engage } \\
\text { Part } 2\end{array}$ & $\begin{array}{l}\text { Students observed } \\
\text { a series circuit } \\
\text { containing two } \\
\text { light bulbs. } \\
\text { Students then } \\
\text { observed that } \\
\text { when one light } \\
\text { bulb was removed } \\
\text { the other light } \\
\text { bulb turned off. } \\
\text { Students engaged } \\
\text { in a discussion } \\
\text { about why and } \\
\text { how this } \\
\text { happened. }\end{array}$ & $\begin{array}{l}\text { - In a series } \\
\text { circuit, the } \\
\text { current } \\
\text { flows from } \\
\text { first light } \\
\text { bulb then } \\
\text { goes second } \\
\text { light bulb, } \\
\text { sharing the } \\
\text { cell or the } \\
\text { source of } \\
\text { electricity. }\end{array}$ & $\begin{array}{l}\text { - } \text { Asking } \\
\text { questions for } \\
\text { science } \\
\text { - Engaging in } \\
\text { argument from } \\
\text { evidence } \\
\text { - Obtaining, } \\
\text { evaluating, and } \\
\text { communicating } \\
\text { information }\end{array}$ & $\begin{array}{l}\text { - Creativity } \\
\text { - Collaboration } \\
\text { - Communication }\end{array}$ \\
\hline $\begin{array}{l}\text { Explore } \\
\text { Part } 2\end{array}$ & $\begin{array}{l}\text { Students designed } \\
\text { and constructed a } \\
\text { circuit that would } \\
\text { allow one bulb to } \\
\text { remain lit when } \\
\text { the other was } \\
\text { removed. }\end{array}$ & $\begin{array}{l}\text { Students } \\
\text { know how } \\
\text { to design } \\
\text { and build } \\
\text { simple } \\
\text { circuits by } \\
\text { using } \\
\text { components } \\
\text { such as } \\
\text { wires, } \\
\text { batteries, } \\
\text { and bulbs. } \\
\text { In a parallel } \\
\text { circuit, each } \\
\text { light bulb } \\
\text { has its own } \\
\text { pathway to } \\
\text { the power } \\
\text { source. }\end{array}$ & 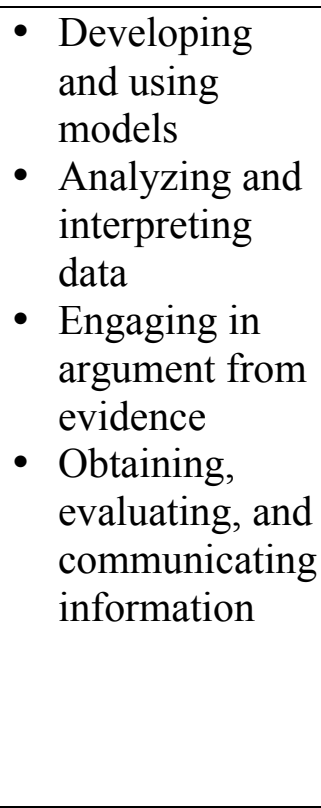 & $\begin{array}{l}\text { - } \text { Creativity } \\
\text { - Collaboration } \\
\text { - Communication }\end{array}$ \\
\hline $\begin{array}{l}\text { Explain } \\
\text { Part } 2\end{array}$ & $\begin{array}{l}\text { Students } \\
\text { discussed their } \\
\text { designs and } \\
\text { evidence } \\
\text { collected from the } \\
\text { construction of } \\
\text { their designs. }\end{array}$ & $\begin{array}{ll}\text { See } \\
\text { objectives } \\
\text { listed above. }\end{array}$ & $\begin{array}{l}\text { - Analyzing and } \\
\text { interpreting } \\
\text { data } \\
\text { - Engaging in } \\
\text { argument from } \\
\text { evidence } \\
\text { - Obtaining, } \\
\text { evaluating, and } \\
\text { communicating } \\
\text { information }\end{array}$ & $\begin{array}{l}\text { - } \text { Creativity } \\
\text { - Collaboration } \\
\text { - Communication }\end{array}$ \\
\hline
\end{tabular}




\begin{tabular}{|c|c|c|c|c|}
\hline $\begin{array}{l}\text { Elaborate } \\
\text { Part } 2\end{array}$ & $\begin{array}{l}\text { Students explored } \\
\text { solar panels as an } \\
\text { alternate source } \\
\text { for powering } \\
\text { simple circuits. }\end{array}$ & $\begin{array}{l}\text { - Solar energy } \\
\text { is harnessed } \\
\text { with solar } \\
\text { collectors } \\
\text { that turn the } \\
\text { radiant } \\
\text { energy into } \\
\text { heat. } \\
\text { Photovoltaic } \\
\text { cells turn } \\
\text { radiant } \\
\text { energy into } \\
\text { electricity. }\end{array}$ & $\begin{array}{l}\text { Defining } \\
\text { problems for } \\
\text { engineering } \\
\text { - Developing } \\
\text { and using } \\
\text { models } \\
\text { - } \text { Designing } \\
\text { solutions for } \\
\text { engineering }\end{array}$ & $\begin{array}{l}\text { - Creativity } \\
\text { - Collaboration } \\
\text { - Communication }\end{array}$ \\
\hline $\begin{array}{l}\text { Evaluate } \\
\text { Part } 2\end{array}$ & $\begin{array}{l}\text { Students were } \\
\text { asked to use the } \\
\text { engineering } \\
\text { design process to } \\
\text { create a circuit } \\
\text { that could be } \\
\text { hooked up in } \\
\text { either series or } \\
\text { parallel to power } \\
\text { two small objects } \\
\text { such as a buzzer } \\
\text { and a fan using a } \\
\text { solar panel as an } \\
\text { energy source. }\end{array}$ & $\begin{array}{l}\text { - The } \\
\text { engineering } \\
\text { design } \\
\text { process is } \\
\text { iterative and } \\
\text { systematic. } \\
\text { The } \\
\text { engineering } \\
\text { design } \\
\text { process is } \\
\text { comprised } \\
\text { of many } \\
\text { stages, } \\
\text { beginning } \\
\text { with } \\
\text { identifying a } \\
\text { problem. } \\
\text { Many } \\
\text { scientific } \\
\text { principles of } \\
\text { energy can } \\
\text { be used to } \\
\text { inform } \\
\text { decisions } \\
\text { about } \\
\text { engineering } \\
\text { design. } \\
\text { See other } \\
\text { objectives } \\
\text { listed above. }\end{array}$ & 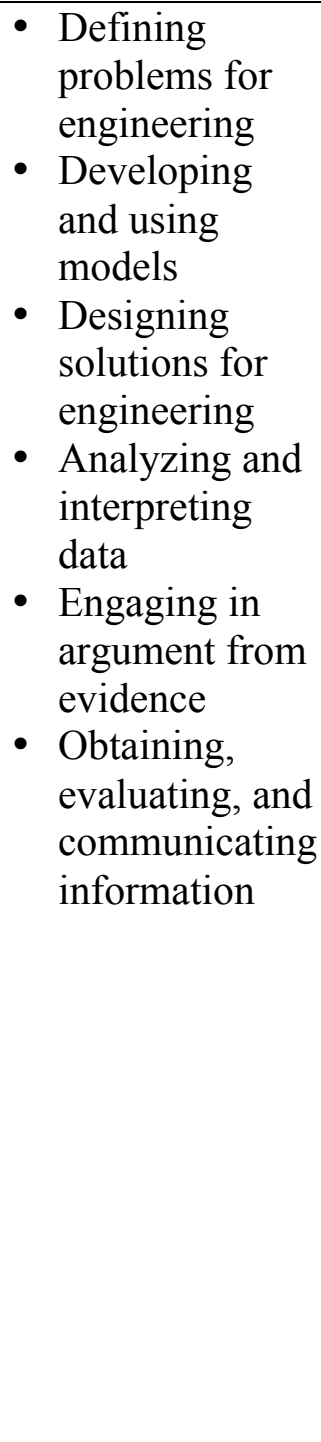 & $\begin{array}{l}\text { - Creativity } \\
\text { - Collaboration } \\
\text { - Communication }\end{array}$ \\
\hline
\end{tabular}


Similar to iteration 1, the QESST research team expected students to understand that energy is transferred between objects and systems (from the sun to the earth and the objects on the earth), and what heating is (a process of transferring energy). Further, it was expected that the students would gain an introductory level understanding of circuits. The research team also expected the students to understand the interaction of science and engineering through use of the engineering design process, modeling, problem solving, and data collection and analysis. Also, regarding student interest and motivation, the researchers expect that students will develop adaptive goals for the future science or engineering careers. Assessments were collected to measure these learning gains. The results are reviewed below.

\section{Analysis}

Analysis of iteration one used a constructivist lens and revealed that whiteboarding was an essential strategy for supporting students in reflecting upon their work and for illuminating student thought processes. In the whiteboarding sessions, students were required to discuss their daily objectives and outcomes as well as engage in scientific argumentation over their thought processes. In these sessions the QESST researcher and educator observed that students were able to describe the energy transfer processes in informal ways but struggled with using the correct terminology (e.g. convection, conduction, and radiation). The whiteboarding sessions allowed the QESST researcher and educator to personalize learning objectives for each team and respond to the unique design problems that each team was having. It was also observed that engineering design was very engaging for the students. They expressed interest in the project at hand and were eager to share insights about the successes and failures of their design. Limited classroom time was the largest obstacle to the instructional method. Scaffolding content knowledge and making engineering practices explicit requires significant time. Students needed time to revise their models in order to further develop their understanding of the energy concepts and experience the iterative nature of the design process; however, the allotment for time in the classroom during this iteration did not allow for the students to revise their models. The second iteration allowed for revisions. Further, researchers developed two assessment tools to more accurately measure the fourth grade students' content knowledge gains and motivation for science and engineering. These pre and post assessments were given in iteration 2. Iteration two also revealed that the engineering design was engaging for students and allowed them to learn scientific concepts about solar energy.

The QESST researchers expected that the students involved in the instructional intervention would result in learning gains during the activity. The content knowledge assessment supported this claim through a statistically significant difference in their improved understanding of solar energy topics from pre to post test. To have a lasting effect on both the instruction provided in the classroom and on student's interests and motivation in studying science in the future, we argue that the intervention must influence teacher and students' goals and beliefs. Research in motivation has demonstrated that teachers are unlikely to engage in instructional innovations unless they are confident in their ability to instruct in this new way ${ }^{15,16}$. Teacher confidence in their instructional skills has been called teaching self-efficacy. Likewise it is important that students' have positive/adaptive goals for learning about science. Mastery goals have been associated with student persistence and increases in interest over time ${ }^{17,18}$. The teacher from this learning experience wrote written reflections each day of instruction, and repeatedly documented 
his increasing interest in solar energy topics, engineering design, and whiteboarding as well as his understanding of the content and pedagogical strategies to implement the content. As a reflection of the classroom environment, we expected students who are exposed to the modeling intervention to develop adaptive goals for their future in science. However, the goal orientation measure revealed that students did not develop a statically significant change in their goal orientations. The results from these measures are instrumental in the development of the instructional unit as it provides a foundation for revision of the curriculum. In order to enact change in students' goal orientations, explicit focus must be made in the classroom to aid students in understanding strategies for developing mastery goals. Additionally, to improve a classroom structure that improves mastery goal orientations student need time to be supported in the activities that support mastery goals. Specifically, students need time to revise their models in order to further develop their understanding of the energy concepts and experience the iterative nature of the design process. Scaffolding content knowledge and making engineering practices explicit requires significant time, but is necessary in order to support students in their mastery goal orientation and deep understanding of engineering design. The end goal of this research project is to provide an effective instructional model using engineering design and modeling that can be disseminated to other science classrooms and design projects in order to support engineering education in the K-12 science classroom. Because of this, it will be important to follow a design-based research methodology and continually revise and improve upon the pedagogical strategies and its support curriculum.

\section{Future Work}

In line with the design research methodology, this study is meant to be a long-term iterative approach to enhance our instructional model. Data from both iteration 1 and iteration 2 will be used to enhance and or re-design the current instructional model. Additionally, the assessments are being revised to provide insight regarding learning and motivational outcomes from future iterations.

\section{Acknowledgements}

This material is based upon work primarily supported by the National Science Foundation (NSF) and the Department of Energy (DOE) under NSF CA No. EEC-1041895. Any opinions, findings and conclusions or recommendations expressed in this material are those of the author(s) and do not necessarily reflect those of the NSF or DOE. 


\section{Bibliography}

1. NAE (National Academy of Engineering) \& NRC (National Research Council) (2009). Engineering in K-12 Education: Understanding the Status and Improving the Prospects. Washington, D.C.: The National Academies Press.

2. (2012). A framework for K-12 science education: practices, crosscutting concepts, and core ideas. Washington, D.C.: The National Academies Press.

3. Bybee, R. (2011). Scientific and Engineering Practices in K-12 Classrooms. Science Scope, 35(4).

4. Hmelo, C., Holton, D., \& Kolodner, J. (2000). Design to learn about complex systems. Journal of the Learning Sciences, 9(3): 247-298.

5. Roth, W. (1995). Inventors, copycats, and everyone else: The emergence of shared resources and practices as defining aspects of classroom communities. Science Education, 79, 475-502.

6. Seiler, G., Tobin, K., \& Sokolic, J. (2001). Design, technology, and science: sites for learning, resistance, and social reproduction in urban schools. Journal of Research in Science Teaching, 38(7): 746-767.

7. Hill, A, \& Smith, H. (1998). Practice meets theory in technology education: a case of authentic learning in the high school setting. Journal of Technology Education, 9(2): 29-45.

8. Ressler, S. \& Ressler, E. (2004). Using a nationwide Internet-based bridge design contest as a vehicle for engineering outreach. Journal of Engineering Education, 93(2): 117-128.

9. Hmelo-Silver, C., \& Azevedo, R. (2006). Understanding complex systems: some core challenges. Journal of the Learning Sciences, 15(1): 53-61.

10. Linn, M. (1995). Designing computer learning environments for engineering and computer science: The scaffolded knowledge integration framework. Journal of Science Education and Technology, 4, 103-126.

11. Megowan-Romanowicz, C. (2010). The modeling method of instruction in physics: How to do it! Presented at the Proceedings of the 2010 Chinese Association of Physics Education and Research Conference. Beijing, China.

12. Wenning, C. J. (2005). Whiteboarding and Socratic dialogues: Questions and answers. Journal of Physics Teacher Education Online, 3(1), 3-10.

13. Bybee, R. W. (2009). The BSCS 5E Instructional Model and 21st Century Skills. National Academies Board on Science Education, Washington, DC: Retrieved March, 4, 2011.

14. Kelly, A. E., Lesh, R. A., Baek, J. H. (2008). Handbook of design research methods in education: Innovations in Science, Technology, Engineering and Mathematics learning and teaching. New York: Routledge.

15. Tschannen-Moran, M., \& Hoy, A. W. (2007). The differential antecedents of self-efficacy beliefs of novice and experienced teachers. Teaching and Teacher Education, 23(6), 944-956.

16. Tschannen-Moran, M., \& Hoy, A. W. (2007). The differential antecedents of self-efficacy beliefs of novice and experienced teachers. Teaching and Teacher Education, 23(6), 944-956.

17. Anderman, E. M., Urdan, T., \& Roeser, R. (2005). The Patterns of Adaptive Learning Survey. In K. A. Moore \& L. H. Lippman (Eds.), What do children need to flourish: Conceptualizing and measuring indicators of positive development. (pp. 223-235). New York, NY, US: Springer Science + Business Media.

18. Harackiewicz, J. M., Barron, K. E., Carter, S. M., Lehto, A. T., \& Elliot, A. J. (1997). Predictors and c 
consequences of achievement goals in the college classroom: Maintaining interest and making the grade. Journal of Personality \& Social Psychology, 73(6), 1284-1295. 